\title{
Correction to: Mind the gap: an analysis of core capacities of the international health regulations (2005) to respond to outbreaks in Yemen
}

Hanan Noman ${ }^{1}$, Fekri Dureab ${ }^{1,2,3^{*}}$, Iman Ahmed ${ }^{4}$, Abdulwahed Al Serouri ${ }^{5}$, Taha Hussein ${ }^{6}$ and Albrecht Jahn ${ }^{1}$

\section{Correction to: BMC Health Serv Res 21, 477 (2021)}

https://doi.org/10.1186/s12913-021-06395-3

Following publication of the original article [1], a funding information was missing in the Funding section.

The updated Funding section is given below and the changes have been highlighted in bold typeface.

Funding

Open Access funding enabled and organized by Projekt DEAL. This work was supported by the Wellcome Trust [grant number: $214686 / \mathrm{Z} / 18 / \mathrm{Z}$ ].

The original article [1] has been corrected.

\section{Author details}

${ }^{1}$ Heidelberg Institute of Global Health, Uniklinikum, Heidelberg, Germany.

${ }^{2}$ Ruprecht-Karls-Universität Heidelberg, Heidelberg, Germany. ${ }^{3}$ IRIA, Akkon-Hochschule für Humanwissenschaften, Berlin, Germany. ${ }^{4}$ Independent Global Health Expert, Montreal, Canada. ${ }^{5}$ Yemen Field Epidemiology Training Program, Ministry of Public Health and Population, Sana'a, Yemen.

${ }^{6}$ Medicines Sans Frontiers -France, Aden, Yemen.

Published online: 09 July 2021

\section{Reference}

1. Noman $\mathrm{H}$, et al. Mind the gap: an analysis of core capacities of the international health regulations (2005) to respond to outbreaks in Yemen. BMC Health Serv Res. 2021;21:477 https://doi.org/10.1186/s12913-021-063 95-3.

The original article can be found online at https://doi.org/10.1186/s12913021-06395-3.

* Correspondence: fekridureab@yahoo.com

${ }^{1}$ Heidelberg Institute of Global Health, Uniklinikum, Heidelberg, Germany

${ }^{2}$ Ruprecht-Karls-Universität Heidelberg, Heidelberg, Germany

Full list of author information is available at the end of the article

(c) The Author(s). 2021 Open Access This article is licensed under a Creative Commons Attribution 4.0 International License, which permits use, sharing, adaptation, distribution and reproduction in any medium or format, as long as you give appropriate credit to the original author(s) and the source, provide a link to the Creative Commons licence, and indicate if changes were made. The images or other third party material in this article are included in the article's Creative Commons licence, unless indicated otherwise in a credit line to the material. If material is not included in the article's Creative Commons licence and your intended use is not permitted by statutory regulation or exceeds the permitted use, you will need to obtain permission directly from the copyright holder. To view a copy of this licence, visit http://creativecommons.org/licenses/by/4.0/. The Creative Commons Public Domain Dedication waiver (http://creativecommons.org/publicdomain/zero/1.0/) applies to the data made available in this article, unless otherwise stated in a credit line to the data. 